\title{
In-situ wh-phrases in Spanish: locality and quantification
}

Ricardo Etxepare et Myriam Uribe-Etxebarria

\section{OpenEdition}

\section{Journals}

Édition électronique

URL : http://journals.openedition.org/rlv/1238

DOI : $10.4000 /$ rlv. 1238

ISSN : 1958-9239

Éditeur

Presses universitaires de Vincennes

Édition imprimée

Date de publication : 1 mai 2005

Pagination : $9-34$

ISBN : 2-84292-167-4

ISSN : 0986-6124

Référence électronique

Ricardo Etxepare et Myriam Uribe-Etxebarria, «In-situ wh-phrases in Spanish: locality and quantification », Recherches linguistiques de Vincennes [En ligne], 33 | 2005, mis en ligne le 16 septembre 2005, consulté le 01 mai 2019. URL : http://journals.openedition.org/rlv/1238 ; DOI 10.4000/rlv. 1238 
Recherches linguistiques de Vincennes 33 - 2005 - p. 9-34

\title{
Ricardo ETXEPARE et Myriam URIBE-ETXEBARRIA CNRS - UMR 5478 et University of the Basque Country
}

\section{IN-SITU WH-PHRASES IN SPANISH : LOCALITY AND QUANTIFICATION ${ }^{1}$}

\begin{abstract}
This paper analyzes in-situ wh-questions in Spanish. It argues that in-situ whphrases in Spanish are actually overtly moved to a left peripheral focus position, their postverbal position being the result of subsequent remnant movement past the focus position. The analysis defended here sets apart the in-situ phenomena of Spanish from the in-situ phenomena occurring in other Romance languages, such as French (as analyzed by Chang, 1997; Bošković, 2000 ; Cheng and Rooryck, 2000), and shows that the purported syntactic mechanisms underlying the distribution of in-situ wh-phrases in those languages are to be amended as far as Spanish is concerned. From a comparative perspective, the Spanish facts support a "pluralistic" approach to in situ strategies (Cheng and Rooryck, 2003), according to which the descriptive notion of in-situ phrase covers a heterogeneous grammatical domain. From a theoretical point of view, our analysis yields support for the idea that many of the phenomena analyzed in the GB tradition in terms of covert movement must be reanalyzed as instances of (masked) overt movement.
\end{abstract}

\section{KEY-WORDS}

Contrastive focus, covert movement, remnant movement, right dislocation, Spanish, wh-in-situ. 


\section{Strategies in question formation : the problem of optionality}

\subsection{Jiménez (1997)}

A cross-linguistic look at question formation strategies will reveal at least three different types of languages: (i) languages with obligatory overt movement; (ii) languages with obligatory in-situ wh-phrases; and (iii) languages with both overt movement and in-situ strategies. French illustrates the last case in pairs such as (1) (Chang, 1997):

a. Qui as-tu vu?
b. Tu as vu qui?

Spanish also seems to have two different strategies of $w$-question formation: one in which the $w h$-phrase moves to the left periphery of the sentence (2a); and one where it stays in-situ (2b) (Jiménez, 1997):

a. ¿Quién ha venido?

b. Ha venido ¿quién?

Jiménez (1997) proposes an account of $(2 \mathrm{a}, \mathrm{b})$ where the wh-phrase optionally moves to the left periphery, the choice being driven by discourse factors, such as the restricted versus unrestricted nature of the domain over which whphrases range: in effect, in-situ wh-phrases in Spanish seem to quantify over heavily restricted domains, as opposed to overtly moved wh-phrases. Consider as an example the following dialogue (Jiménez, 1997 : 42):

(3) Speaker A: Mi padre, mi madre y yo fuimos a la tienda a comprar huevos, leche y café.

'My father, my mother and I went to the store to buy eggs, milk and coffee.'

Mi madre compró los huevos.

'My mother bought the eggs.'
a. Speaker B :
¿Qué compró tu padre?
b. Speaker B :

Y tu padre compró ¿qué?
and your father bought what

For an in-situ question such as (4b) to be felicitous, we need a context such as (3). Afterwards, speaker B can utter (4b), assuming that: (i) the father of Speaker A bought something; and (ii) the item bought comes from a preestablished set (the milk, eggs and coffee set). For Jiménez, (4a) and (4b) have different presuppositions, illustrated in (5a) and $(5 b)$ respectively:
a. $\left\{\right.$ p: $\exists(a) \in D\left[p=\|\right.$ bought $\left.\left.\left(f, x_{1}\right) \| g(a / x)\right]\right\}$
b. $\left\{\right.$ p: $\exists(a) \in\{$ eggs, milk, coffee $\}\left[p=\|\right.$ bought $\left.\left.\left(f, x_{1}\right) \| g(a / x)\right]\right\}$ 
Whereas in $(4 a, 5 a)$ the domain of quantification is the contextually restricted domain of individuals, in $(4 b, 5 b)$ it is a designated set, itself a subset of the contextually restricted domain of individuals. The event presupposition pointed out by Jiménez, however, is not a side effect of the restricted quantification. First, observe that there is a subtle but nonetheless noticeable difference in the felicitousness of the following sentences:
a. Cuando compró algo, tu padre compró ¿qué? when he-bought something your father bought what
b. ??Si compró algo, tu padre compró ¿qué? if he-bought something your father bought what
a. Cuando compró algo, ¿qué compró tu padre? when he-bought something what bought your father
b. Si compró algo, ¿qué compró tu padre? if he-bought something what bought your father

Whereas in $(6 a, 7 a)$ the clause initial temporal adjunct presupposes the existence of a buying event, in $(6 b, 7 b)$ the conditional leaves open whether there was a buying or not. Whereas the temporal adjunct can be followed either by a preverbal or an in-situ wh-question, the conditional adjunct is degraded when followed by an in-situ wh-question. The effect does not arise with discourse-linked (Pesetsky, 1987; 2000) initial partitive wh-phrases, which quantify over designated, restricted sets :

$$
\begin{array}{llll}
\mathrm{Si} \text { compró algo, ¿cuál de esas tres cosas compró? } \\
\text { if he-bought } & \text { something } & \text { which one of those three things he-bought }
\end{array}
$$

We dispute Jimenez's syntactic claim that there is any optionality in question strategies (movement versus in-situ) in Spanish: as we will see, the elaboration of an event presupposition has a syntactic counterpart in the topicalization of IP, whereas the restricted interpretation of the $w h$ quantification in the in-situ cases is related to the fact that wh-phrases in-situ are contrastively focused. As all contrastively focused constituents in Spanish (see Campos and Zampini, 1990; Uriagereka, 1995 ; Etxepare, 1997, among others), the wh-phrase in focus undergoes overt movement to an IP-external position. In-situ $w h$-strategies in Spanish are thus the product of quite a complex syntactic derivation: the in-situ wh-phrase undergoes focus movement to a left peripheral focus position, and this movement is followed by remnant topicalization of the IP. We will see that our analysis explains a wide range of syntactic phenomena belonging to the in-situ strategy. It also supports a restricted view of syntactic derivations, according to which optionality is a marked or altogether absent feature of the computational system, movement operations being directly enforced by grammatical 
features, in the spirit of the minimalist program (Chomsky, 1995, 2001a, 2001b; but see Fukui 1993, for an economy driven notion of optionality).

\subsection{French}

The problem posed by the apparent optionality of mixed wh-question strategies, such as the one in Spanish or French, has been specifically addressed in work by Bošković (2000), Cheng and Rooryck (2000), and Mathieu (2002). Bošković (1997) argues that lexical insertion can take place at $\mathrm{LF}$ and proposes that French has a null $\mathrm{C}$ with a strong $w h$-feature which, due to the Last Resort Condition, is not inserted until LF. The late insertion of this $\mathrm{C}$ explains why elements do not move in overt syntax. The Extension Condition together with the locality of LF feature movement explains why insitu wh-phrases are limited to matrix sentences. Bošković's analysis is meant to account for the following asymmetry ${ }^{2}$ :
a. Marie a acheté quoi?
Marie has bought what
b. *Marie pense que Jean a acheté quoi?
Marie thinks that Jean has bought what
$\begin{array}{clll}\text { c. *Marie se demande } & \text { si Jean a acheté quoi? } \\ \text { Marie } & \text { wonders } & \text { if Jean has bought what }\end{array}$

(9a) corresponds to the late (LF-) insertion of the null complementizer; the strong feature of the covert complementizer covertly attracts the wh-features of the in-situ wh-phrase. Feature movement is sensitive to the presence of an overt intermediate complementizer, so the derivation crashes at LF in (9b, c). However, we must say that the set of judgments in (9) does represent a widespread variety of spoken French, which in fact allows structures like (9b).

Cheng and Rooryck (2000) propose that in-situ wh-phrases in French are licensed by an intonational morpheme [Q:], which is underspecified as to its function as a yes/no question operator or as a wh-question operator. This underspecified morpheme gets disambiguated as [Q: $w h$ ] by feature movement at LF. The root properties of this morpheme account for why insitu elements are only licensed in matrix clauses $(c f .(9 \mathrm{~b}, \mathrm{c}))$. The two accounts explain the apparent optionality in terms of a particular lexical property of French complementizers. Both analyses share the following features: (i) wh-phrases do not move in the overt syntax in the in-situ strategy; (ii) licensing takes place by feature movement at LF; and (iii) as a corollary, insitu wh-phrases can only be licensed in matrix clauses. However, as we noted before, structures like (9b) are allowed in common spoken French.

Feature movement is also claimed to account for the following restrictions: in-situ wh-phrases in French cannot be preceded by quantifiers, negation or modals (a fact observed by Chang, 1997; Bošković, 1997; and Cheng and Rooryck, 2000). 

a. ??Tous les étudiants ont rencontré qui?
b. ??Chaque étudiant a rencontré qui ?
c. ??Il n'a pas rencontré qui ?
d. ??Il peut rencontrer qui?
e. ??Il admire toujours qui?

According to Cheng and Rooryck (2000), movement of the wh-feature creates an operator-indefinite configuration. Following Honcoop (1997), they assume that negation, modals and quantifiers create an inaccessible domain for the head of the chain and the indefinite to be linked (see also Beck, 1996) ${ }^{3}$. The basic LF-configuration of the sentences in (10) is a split operator structure (see Mathieu, 2002), where the $w h$-features raise to the matrix Comp and the indefinite restriction of the wh-phrase remains in-situ. This yields a LFconfiguration where the operator c-commands the indefinite, but not the head of the chain. Again, as in the case of (9), the paradigm does not seem to represent common spoken French, where structures like $(10 \mathrm{c}, \mathrm{d})$ can be fully acceptable while (10a) is odd whether the wh-phrase moves overtly or not. Generally speaking there may exist so far poorly understood differences in terms of contextual compatibility (as in the case of (9) above, too). Pending an assessment of the facts reported in Bošković's and Cheng and Rooryck's work, which may force us to rethink the syntactic status of wh-in-situ in French, the French facts stand in clear contrast to Spanish.

The in-situ analysis of postverbal wh-phrases in French also accounts for the fact that some adverbs, such as pourquoi "why", are not good in that position:

$$
\begin{aligned}
& * \text { Il est venu pourquoi? } \\
& \text { he is come why }
\end{aligned}
$$

One could assume, with Rizzi (1990), that the placement of those adverbs is necessarily IP-external, since they inherently modify propositional objects. If that is the case, the ungrammaticality of (11) follows naturally under the assumption that the postverbal position of wh-phrases in French is VP internal. VP-internal adjuncts cannot modify propositions (see also Cinque, 1999).

\section{Syntactic distribution of in-situ wh-phrases in Spanish}

The in-situ wh-strategy in Spanish seems to be of an altogether different type. As we will try to show in this section, in-situ wh-phrases are not truly in-situ. First, they are not just postverbal, but their position can be more precisely defined as the rightmost one (Uribe-Etxebarria, 2002). They can be embedded and show no intervention effect of the sort in (10). Furthermore, they show no argument/adjunct asymmetry in the purported in- 
situ position of $w h$-phrases. Arguments and adjuncts do show some surprising asymmetries, though, which can easily be accounted for in terms of overt whmovement. We will also see that binding asymmetries also suggest an overt movement account of in-situ wh-phrases. Finally, in-situ wh-phrases in Spanish also differ from the French ones in their interaction with other scope taking operators, such as quantifiers.

\subsection{The sentence final requirement (Uribe-Etxebarria, 2002)}

\subsubsection{Unmarked word order and the position of the in-situ wh-phrase}

In contrast with regular wh-questions, in-situ questions in Spanish show an intonational pattern similar to declarative sentences, with a clear intonational break between the $w h$-phrase, which is heavily stressed and has downward intonation, and the material preceding it:

$$
\text { [Declarative melody }(\mathrm{Y}) \text { vosotros habeis comprado] [Interrogative melody qué]? }
$$

This intonational pattern goes together with some intriguing positional restrictions vis-à-vis the wh-phrase. Wh-phrases must be "sentence final":

$$
\begin{aligned}
& \text { a. Sergio llegó el martes en bicicleta } \\
& \text { Sergio arrived on Tuesday by bicycle } \\
& \text { b. *Sergio llegó cuándo en bicicleta? } \\
& \text { Sergio arrived when by bicycle } \\
& \text { c. Sergio llegó en bicicleta cuándo? } \\
& \text { Sergio arrived by bicycle when }
\end{aligned}
$$

(13a) shows the unmarked word order in a declarative sentence, in which the temporal adverb el martes 'on Tuesday' precedes the instrumental adverb en bicicleta "by bicycle". (13b) shows that the wh-phrase in-situ cannot occupy the natural, unmarked position of the adverb. (13c) shows that the "in-situ" wh-phrase is acceptable in the final, rightmost position of the sentence. The same generalization seems to apply to (14):

$$
\begin{aligned}
& \text { a. Pedro se ha casado con María por la iglesia } \\
& \text { Pedro CL has married with Maria through the church } \\
& \text { b. *Pedro se ha casado con quién por la iglesia? } \\
& \text { Pedro CL has married with whom through the church } \\
& \text { c. Pedro se ha casado por la iglesia ¿con quién? } \\
& \text { Pedro CL has married through the church with whom }
\end{aligned}
$$

We have to be careful here, though: cases such as (14b) become possible with a "right dislocation" intonation and a pause between the postverbal wh-phrase and the following constituent (which we represent with an intervening comma): 


$$
\begin{aligned}
& \text { Pedro se ha casado ¿con quién?, por la iglesia } \\
& \text { Pedro CL has married with whom, through the church }
\end{aligned}
$$

The syntactic position of the right dislocated constituent is an important point, in view of recent analyses of right dislocation (such as Cecchetto, 1999) which argue in favor of an IP-internal position for right dislocated constituents. Under our analysis of the in-situ phenomenon in Spanish, in which the rightmost position of the wh-phrase is the result of two subsequent operations (focalization of the wh-phrase to an IP external projection and remnant topicalization of the IP), the position of the right dislocated constituent cannot be IP internal, as it would be carried along with the topicalized IP.

\subsubsection{Right dislocation and Marginalization in Spanish}

There is empirical evidence that right dislocated constituents are not inside IP in Spanish. Consider for instance the scope and referential properties of right dislocated constituents :
a. Pedro no (le) ha dejado nada ¿a quién? Pedro neg CL has left anything to whom 'Who is the person $\mathrm{x}$ such that Pedro did not leave anything for him?'
b. ??Pedro no (le) ha dejado ¿a quién?, nada? Pedro neg $\mathrm{CL}$ has left to whom anything
a. Pedro no (le) ha dado a nadie ¿qué? Pedro neg CL has given to anyonewhat
b. ??Pedro no (le) ha dado ¿qué?, a nadie?
Pedro neg CL has given what, to anyone

The structures in (16-17) show that certain elements, such as negative polarity items, cannot occur following the wh in-situ ${ }^{4}$. Negative polarity items make bad topics, as we know:

$$
\begin{aligned}
& \text { a. ??Nada, Juan no ha comprado } \\
& \text { anything, Juan neg has bought } \\
& \text { b. *A nadie, nosotros no visitamos ayer } \\
& \text { to anyone we neg visit yesterday }
\end{aligned}
$$

It is reasonable to suggest that the impossibility of right and left dislocations with negative polarity items should be somehow related. A straightforward way to do it is to assume that right and left dislocated constituents occupy the same syntactic position. Whatever causes $(18 \mathrm{a}, \mathrm{b})$ to be ungrammatical then, also accounts for the ungrammaticality of $(16 \mathrm{~b}, 17 \mathrm{~b})$. We know however that right and left dislocations are not equal. In a recent analysis of the phenomenology of right dislocation, Cardinaletti (2002) distinguishes two 
different syntactic strategies placing phrases to the right which she calls Right Dislocation and Marginalization. The two strategies are distinguished, among other things ${ }^{5}$, by: (i) the presence vs. absence of a doubling clitic (CL) ( $c f$. (19)); (ii) the free word order of Right Dislocated constituents vs. the fixed order of Marginalized elements ( $c f$. (20-21)); (iii) the scope of the postverbal element in each of the cases (cf. (22)); (iv) the position of objects in embedding constructions ( $c f$. (23)); and (v) the possibility of extracting an operator from constituents placed to the right (cf. (24)) (Cardinaletti, 2002):
a. L'ho
già
comprato, il giornale.
Right Disl.
CL I-have already bought the journal
'I have already bought it, the journal.'
b. Ho già comprato, il giornale.
Marginal.

a. Ce l'ha nascosto, il bambino, il libro, sotto il letto. R. D. there CL has hidden the child, the book, under the bed

b. Ce l'ha nascosto, il bambino, sotto il letto, il libro.

a. Ha nascosto il bambino, il libro, sotto il letto.

Marg.

b. ??Ha nascosto il bambino, sotto il letto, il libro.

a. *Non l'ha invitato Gianni, nessuno.

NEG CL has invited Gianni, anyone

b. No, non ha invitato Gianni, nessuno. Marg.

a. Che cosa l'hai convinto a fare, a Mario? R. D. which thing CL have-you convinced to do, to Mario

b. *Che cosa hai convinto a fare, Mario? Marg.

a. *Che $\operatorname{cosa}_{\mathrm{i}}$ l'ha detto, Gianni, [che avrebbe fatto $\mathrm{t}_{\mathrm{i}}$ ]? R. D. which thing CL has said, Gianni, that he-would do

b. Che $\operatorname{cosa}_{\mathrm{i}}$ ha detto, Gianni, [che avrebbe fatto $\mathrm{t}_{\mathrm{i}}$ ]

As shown in (19) to (24), the presence $v s$ absence of clitic doubling is associated with a wide range of syntactic differences. Those syntactic differences, according to Cardinaletti, are to be structurally analyzed in terms of two different configurations. In one (Marginalization), the right dislocated constituent has all the properties of an in-situ phrase: it does not involve a clitic ( $c f .(19 \mathrm{~b})$ ); the order of the postverbal constituents is fixed, allowing only the unmarked one ( $c f$. (20) vs. (21)); negative polarity items are licensed in their dislocated position ( $c f .(22))$; objects must occur close to the predicate that selects them ( $c f .(23))$; and finally, extraction out of marginalized clauses is allowed, unlike in the case of right dislocated constructions (cf. (24)). Cardinaletti proposes that marginalized elements are in-situ destressed constituents (see 25a), whereas right dislocated ones are high in the structure, their postverbal position the result of IP-movement (see 25b): 
a. [IP ha [AspP comprato $_{\mathrm{i}} \mathrm{Asp}^{0}$ [VP Gianni ti il giornale]]]

b. [XP [IP l'ho comprato] $\mathrm{X}^{0}$ [DP il giornale]]

Spanish is like Italian in that right dislocation need not have to be supported by a clitic:
a. Ya he comprado, el periódico. already I-have bought the journal
b. Ya lo he comprado, el periódico. already CL I-have bought, the journal

But it fails to show the properties that Cardinaletti associates to Marginalization. As we already showed, right dislocations without a clitic do not license negative polarity items in the postverbal domain ( $c f$. (16b), (17b)). Furthermore, the cliticless cases allow the postverbal constituents to be freely ordered $(c f$. (27)), they allow objects to be separated from their selecting predicates $(c f .(28))$, and disallow extraction ( $c f .(29))$ :

(27) a. (Lo) ha escondido el crío, bajo la cama, el libro CL has hidden the child under the bed the book

b. (Lo) ha escondido el crío, el libro, bajo la cama.
a. ¿Qué (le) has propuesto hacer, a Mario? what CL have-you proposed to-do to Mario
b. ¿Qué (le) has propuesto a Mario hacer?
a. ??¿Qué cosaha dicho, Juan, [CP que haría $\left.\mathrm{t}_{\mathrm{i}}\right]$ ? What has said Juan that he-would do
b. * ¿Qué cosa lo ha dicho, Juan, [CP que haría $\left.\mathrm{t}_{\mathrm{i}}\right]$ ?

In this regard, cliticless right dislocation constructions are similar to clitic doubling cases. We therefore conclude that right dislocation constructions in Spanish are always external to the IP, leaving aside the issue of the precise syntactic configuration that distinguishes them from one another.

\subsubsection{Other in-situ constructions}

The sentence final requirement is not operative in true in-situ configurations such as echo questions (30) and multiple wh-questions (31):
a. ¿Que Sergio se ha casado con quién por la iglesia? that Sergio CL has married with whom through the church
b. ¿Que no sabes que llegó cuándo en bicicleta? that neg you-know that he-arrived when by bicycle
a. ¿Quién se ha casado con quién por la iglesia? who CL has married with whom through the church
b. ¿Quién llego cuándo en bicicleta? who arrived when by bicycle


The sentence final requirement is not exclusive of in-situ $w h$-questions. It also arises in contrastive focus. If we substitute the in-situ wh-phrases with a DP in (13) and (14), what we get is a contrastive focus construction:
a. Sergio llegó en bicicleta EL MARTES.
b. Pedro se ha casado por la iglesia CON MARIA.

Contrastive foci also induce the "right dislocation" of post-focal elements :
a. Sergio llegó EL MARTES, en bicicleta.
b. Pedro se ha casado CON MARIA, por la iglesia.

Those elements which cannot occur right dislocated are excluded from the postfocal position, e.g. polarity items $(c f .(16 \mathrm{~b}, 17 \mathrm{~b}))$ :
a. *Sergio no llegó
EL MARTES, con nadie.
Sergio neg arrived on Tuesday with anyone
b. *Pedro no se ha casado CON MARIA, por ninguna razón.
Pedro neg CL married with Maria, for any reason

Observe that this does not happen with in-situ questions in multiple whquestions :
a. ¿Quién no llegó qué día con nadie? who neg arrived which day with anyone
b. ¿Quién no se ha casado con quién por ninguna razón especial? who neg CL has married with whom because of no special reason

The fact that contrastive foci show the same restrictions as (single) in-situ questions in Spanish and that the interpretation of in-situ wh-questions implies a restricted set of alternatives, as contrastive foci do (see UribeEtxebarria, 2002) lead us to conclude that in-situ wh-phrases are instances of contrastive focus.

\subsection{Adjuncts and Island restrictions in in-situ wh-questions}

As in Portuguese (Cheng and Rooryck, 2003), adjunct wh-phrases such as por qué "why" or cómo "how" can occur in-situ in Spanish:

$$
\begin{aligned}
& \text { a. Y tú } \\
& \text { and you has venido ¿porqué? } \\
& \text { b. Tus amigos han llegado ¿cómo? } \\
& \text { your friends have arrived how }
\end{aligned}
$$

The occurrence of adjuncts such as why in postverbal positions is problematic under the view that postverbal wh-phrases are truly in-situ in Spanish (as French shows). It is unproblematic under the view that postverbal wh-phrases in Spanish actually occupy a position in the left periphery as contrastive foci ${ }^{6}$. 
Both adjunct and argument wh-phrases can occur postverbally in embedded domains :

Juan dice que María compró eso ¿en qué tienda/dónde?

Juan says that Maria bought that in which shop/where

Argument $w h$-phrases can also be embedded in interrogative dependents, with matrix scope ${ }^{7}$ :
$\begin{array}{lllllll}\text { a. Y tú no sabes si ha } & \text { venido ¿quién? } \\ \text { and you neg know } & \text { if } & \text { has come who }\end{array}$
'Who is such that you don't know whether he came?'

b. Y Juan se pregunta dónde ha ido ¿quién?

'Who is such that John wonders where he is?'

When embedded in $w h$-dependents, wh-phrases in-situ with matrix scope give rise to argument/adjunct asymmetries :

a. Y tú no sabes cómo llegó ¿quién?

and you neg know how arrived who

'Who is such that you don't know how he/she arrived?"

b. *Y tú no sabes quién llegó ¿cómo?

and you neg know who arrived how

'What is the way/state such that you don't know who arrived in that way/state?'

(40) a. Tú te preguntas con quién se ha ido ¿quién?

you CL wonder with whom $\mathrm{CL}$ has left who

'Who is such that you wonder with whom he/she left?'

b. *Tú te preguntas quién se ha ido ¿con quién? you CL wonder who CL has left with whom

'Who is such that you wonder who left with him/her?'

(41) a. Tú no sabes de qué se ha muerto ¿quién? you neg know of what CL has died who

'Who is such that you don't know of what he died?'

b. ¿¿De qué no sabes quién se ha muerto?

of what neg you-know who CL has died

'What is such that you don't know who died of it?'

Given the fact that $w h$-adjuncts can be left in-situ, the reason of the ungrammaticality of the (b) cases must be directly related to the presence of a $w h$-dependency. The asymmetry is hard to state if we assume the wh-phrases to be in-situ. The facts however are easy to account for under a movement approach. In fact, the asymmetry is a well known one in overt wh-movement in Spanish: 
a. ¿Quiénno sabes cómo llegó?

who neg know how arrived

"Who is such that you don't know how he/she arrived?"

b. ??¿Cómo no sabes quién llegó

how neg know who arrived

"*How don't you know who arrived?"

a. ¿Quién te preguntas con quién se ha ido? who CL wonder with whom $\mathrm{CL}$ has left

'Who is such that you wonder with whom he/she left?'

b. * ¿Con quién te preguntas quién se ha ido?

with whom CL wonder who $\mathrm{CL}$ has left

'Who is such that you wonder who left with him/her?'
a. ¿Quién no sabes de qué se ha muerto?
who negknow of what CL has died
'Who is such that you don't know what he died of?'
b. ¿¿De qué no sabes quién se ha muerto?
of what neg know who CL has died
'What is such that you don't know who died of it?'

The striking parallelism between (39)-(41) on the one hand and (42)-(44) on the other can be straightforwardly accounted for under the hypothesis that the rightmost position of in-situ wh-phrases is the result of two subsequent movements: (i) overt wh-movement to the left periphery, arguably to a focal/wh-position; and (ii) remnant movement of the non-focal part to a higher topic position. (45) is an illustrative derivation:

a. [FP quién ${ }_{i} F^{0}$ [IP no sabes [ ${ }_{C P}$ de qué $\mathrm{C}^{0}$ [se ha muerto $\left.\left.\left.t_{i} t_{j}\right]\right]\right]$

b. $\left[\mathrm{TopP}_{\mathrm{TIP}}\right.$ no sabes $\left[\mathrm{CP} \text { de qué } \mathrm{C}^{0}\left[\text { se ha muerto } \mathrm{t}_{\mathrm{i}} \mathrm{t}_{\mathrm{j}}\right]\right]_{\mathrm{k}}$ Top $^{0}\left[\mathrm{FP}\right.$ quién $\left.\mathrm{F}^{0} \mathrm{t}_{\mathrm{k}}\right]$ ]

(45a) illustrates the movement of the subject $w h$-phrase to a matrix scope position and (45b) remnant movement of the non-focal material to the highest topic position. If the first movement is not possible (as in (44b)), then the subsequent step is not possible either ( $c f$. the ungrammaticality of (41b)). The logic of the argument leads us to expect that in-situ adjuncts will be bad in any context in which adjunct extraction is not possible. The effect we find in (39) to (41) can in fact be reproduced in other weak island configurations, such as factive islands ( $c f$. (46)), negative islands ( $c f$. (47)) or extraposition islands $(c f .(48))^{8}$. All of them allow argument extraction.
a. $*_{\text {¿De qué/porqué }}$ i sabe tu padre que murió Pedro $t_{i}$ ? of what/why knows your father that died Pedro 'What is such that your father knows that Pedro died of it/because of it?'
b. *Tu padre sabe que Pedro murió de qué/porqué? your father knows that Pedro died of what/why


a. * ¿De qué/porqué ${ }_{i}$ no dijeron que hubiera muerto $t_{i}$ ? of what/why neg they-said that he-had-subj died 'What is such that they did not say that he had died of it/because of it?'

b. *No dijeron que hubiera muerto de qué/porqué?

a. * ¿De qué/porqué ${ }_{i}$ tiene interés que haya muerto $t_{i}$ ? of what/why has interest that he-has-subj died 'What is such that it is interesting that he died of it/because of it?'

b. *Tiene interés que haya muerto ¿porqué/de qué?

The derivation proposed in (45) is well attested in contexts of contrastive focus. Consider for instance the following cases :

$\mathrm{Tu}$ hermano ha compradocreo/parece/Juan dice que UN TOYOTA your brother has bought I-think/it-seems/Juan says that a Toyota 'Juan says/I think/it seems that your brother has bought a TOYOTA.'

In (49), the focalized element is the only constituent following the complementizer que. The focus, on the other hand, is the object of a sentence which shows up in the matrix periphery, as a topicalized element. The only possible derivation for a sentence such as (49) is one where the focus moves first to an embedded preverbal focus position, and then the remnant is topicalized to the left periphery of the matrix clause :

(50) a. Creo que [FP [UN TOYOTA $]_{\mathrm{i}} \mathrm{F}^{0}$ [tu hermano ha comprado $\mathrm{t}_{\mathrm{i}}$ ]

b. [TopP [IP Tu hermano ha comprado $\left.t_{i}\right]_{T^{0}}$ Top $^{0}$ [creo que [FP [UN TOYOTA $]_{i}$ $\left.\left.\mathrm{F}^{0} \mathrm{t}_{\mathrm{j}}\right]\right]$

\subsection{Binding asymmetries}

Consider the following paradigm:

(51) a. Tus amigos han visto una foto de sí mismos your friends have seen a picture of themselves

b. *Tus amigos creen que María ha visto una foto de sí mismos your friends believe that Maria has seen a picture of themselves

c. *QQuiénes creen que María ha visto qué foto de sí mismos? who-pl believe that Maria has seen a picture of themselves

(52) a. ¿[Qué foto de sí mismos] $]_{\mathrm{i}}$ creen tus amigos que María ha visto $t_{i}$ ?

what picture of themselves believe your friends that Maria has seen

b. Tus amigos creen que María ha visto ¿qué foto de sí mismos? your friends believe that Maria has seen what picture of themselves

(51a, b) show that the complex anaphor sí mismos "themselves" is not licensed long distance (Reinhart and Reuland, 1991, 1993). (51c) shows that 
the local licensing of the complex anaphor is preserved in in-situ configurations ${ }^{9}$. (52a-b) illustrate the fact that moving the wh-phrase creates new binding options. Following Chomsky (1993), we will say that these new binding options arise from the presence of copies of the moved $w h$-phrase in intermediate positions. Those intermediate positions are in a sufficiently local relation to the antecedent to allow coreference. Thus, in (52b), a copy of the wh-phrase qué foto de sí mismos occupies the intermediate Spec of Comp. The anaphor inserted in the $w h$-phrase is then sufficiently close to the antecedent to be bound by it. The cyclic licensing of the anaphor provides an elegant account of the contrast between (51c) and (52b). In the first case, the anaphor, inserted in the in-situ wh-phrase, cannot reach the matrix antecedent, since its binding domain is the embedded clause. In the light of that case, we must now consider (52b). If we assume that the sentence final $w h$-phrase is insitu, it will be extremely difficult to account for the fact that the complex anaphor can be bound by the matrix subject. On the other hand, a movement account of those in-situ cases provides a ready solution for the grammaticality of (52b): cyclic movement of the in-situ wh-phrase to a matrix focus position allow for a copy in the intermediate Comp, as shown in (53).

[FP [Qué foto de sí mismos] $\mathrm{F}^{0}$ [IP creen tus amigos [CP (qué foto de sí mismos) que...

Subsequent movement of the remnant IP past the wh-phrase masks the overt movement of the wh-phrase.

\subsection{Intervention effects}

Unlike in the French dialects/idiolects analyzed in Chang (1997), Cheng and Rooryck (2000), in-situ wh-phrases in Spanish show no intervention effect:

(54) a. Todo el mundo compra ¿dónde?

all the world buys where

'Where does everyone buy?'

b. Pedro alaba siempre ¿a quién?

Pedro praises always who

c. Los niños juegan cada día ¿con qué?

the children play each day with what

d. Nadie compró ¿qué? noone bought what

e. Y tú no viste ¿a quién? and you neg saw to whom

d. Y tú puedes comprar ¿qué? and you can buy what 
Both Bošković (1997) and Cheng and Rooryck (2000) explain the intervention effect as a side effect of feature movement. In-situ wh-phrases are targeted for $w h$-feature movement to the wh-complementizer. For Bošković, feature movement is head movement ( $c f$. section 1.2, above), and head movement cannot cross Neg. For Cheng and Rooryck (2000; see also Pesetsky, 2000), feature movement, attracting just the operator features of the wh-phrase, creates an operator-indefinite chain which is also subject to the intervention effects discussed in section 1.2. In any case, the Spanish facts show that the mechanism by which apparent in-situ wh-phrases take matrix scope in Spanish is not (covert) feature movement. Our analysis in terms of overt focus movement of the wh-phrase readily accounts for the contrast.

\section{Scope interactions}

An intriguing feature of Spanish in-situ wh-phrases is that they show no scope interactions with other quantifiers, unless the quantifiers are doubled with a clitic. Consider for instance the following cases combining an in-situ wh-phrase and a universal quantifier:
a. ¿Quién compró cada libro? who bought each book
b. Compró cada libro ¿quién? bought each book who
c. Cada libro lo compró ¿quién? each book CL bought who

Whereas one can answer a question such as (55a) either by providing a list of buyers and books bought (the most natural answer) or by naming the unique individual who bought each and everyone of the books, (55b) only allows an individual answer. That is, it asks who is the individual $\mathrm{x}$ such that $\mathrm{x}$ bought each one of the books. No other reading is available. A pair-list reading however becomes possible if we clitic left dislocate the quantifier. In other words, (55c) also allows an answer providing a list of buyers and books. The same contrast arises in (56). (56) involves a universal quantifier indirect object and an object $w h$-phrase :
a. ¿A quién han enviado cada libro? to whom they-have sent each book?
b. Han enviado cada libro ia quién? they-have sent each book to whom
c. Cada libro se lo han enviado ¿a quién? each book CL CL they-have sent to whom


Whereas the most natural reading of (56a) implies a list of books and people who received them, (56b) only admits an individual answer. It asks who is that individual to whom each and everyone of the books were sent. By clitic left dislocating the quantifier, we obtain a pair-list reading again. The configurations involving a quantificational subject and a $w h$-object give rise to ambiguous readings:
a. ¿Qué compró cada alumno? what bought each student
b. Cada alumno compró ¿qué? each student bought what

Unlike in previous cases, here the configuration in which the quantifier precedes the $w h$-phrase, (57b), does give rise to a pair-list answer. The asymmetric behaviour of the subject in this regard must be linked to the hypothesis that preverbal subjects in Spanish are dislocated (Olarrea, 1996; Ordoñez, 1997), in a configuration analogous to the clitic doubling cases:

$$
\text { [TopP cada alumno } \text { Top }^{0} \text { [IP } \text { pro }_{i} \text { compro qué]] }
$$

If that is the case, then the actual configuration in which a pair-list reading becomes possible corresponds to the dislocated structure. The relevant generalizations are illustrated by the following table:

\begin{tabular}{|cc|}
\hline Wh... $\mathbf{Q P} . . \mathbf{t}_{\text {wh... }}$ \\
(i) & Distributive \\
(ii) & Individual \\
$\mathbf{Q P} .$. Wh... \\
(i) & *Distributive \\
(ii) & Individual \\
{$[\mathbf{Q P}]_{\mathbf{i}}$... } & $\mathbf{C L}_{\mathbf{i}}$... Wh... \\
(i) & Distributive \\
(ii) & Individual \\
\hline
\end{tabular}

The Spanish facts contrast sharply with the French ones as discussed by Mathieu (2002: 83). In French, the only possible reading for a sentence in which the universal quantifier precedes the in-situ wh-phrase is the distributive one :

(60) a. Tous les enfants ont fait quoi? all the children have done what

(i) *Which $\mathrm{x}, \mathrm{x}$ a thing, every $\mathrm{y}, \mathrm{y}$ a child did $\mathrm{x}$

(ii) For which pair $\langle x, y\rangle$, every $x, x$ a child, did $y, y$ a thing 
b. Tu as donné tous les vêtements à qui? you have given all the clothes to whom

(i) *Which $\mathrm{x}, \mathrm{x}$ a person, you gave every $\mathrm{y}$, $\mathrm{y}$ a piece of clothing, to $\mathrm{x}$

(ii) For which pair $\langle x, y\rangle$, you gave every $x, x$ a piece of clothing, to $y$

The French readings are the exact opposite of the Spanish ones. The Spanish facts have a straightforward account in our analysis, if we combine it with the standard claim that a distributive reading can only arise in a configuration where the universal quantifier c-commands the wh-phrase. In our analysis, the wh-phrase is in a scope position, and preceded by an IP which itself contains the quantifier. Consider as an example (55b), which we repeat as (61), and the proposed syntactic structure:
a. Compró cada libro ¿quién? bought each book who
b. $\left[{ }_{\text {TopP }}\left[\mathrm{t}_{\mathrm{i}} \text { compró cada libro }\right]_{\mathrm{j}} \operatorname{Top}^{0}\left[{ }_{\mathrm{FP}}\right.\right.$ quién $\left.\left.\mathrm{n}_{\mathrm{i}} \mathrm{F}^{0} \mathrm{t}_{\mathrm{j}}\right]\right]$

In the syntactic structure which results from the combination of focus movement and remnant topicalization, the quantifier phrase does not ccommand the wh-phrase, and no scope interaction is possible. Now, consider the cases in which the quantifier phrase is clitic left dislocated. In those cases, the quantifier itself can be inserted in the syntactic structure outside of the IP, its place being occupied by the clitic. If topic positions can be recursive (or they provide more than one specifier, in accordance with the assumptions of bare phrase structure, Chomsky, 1995), the clitic left dislocated quantifiers sit in a higher topic position, from which they c-command the wh-phrase:

$$
\left[\text { TopP } [ \text { cada libro } ] _ { \mathrm { k } } \operatorname { T o p } ^ { 0 } \left[{ }_{\text {TopP }}\left[\mathrm{t}_{\mathrm{i}} \operatorname{lo}_{\mathrm{k}} \text { compró }_{\mathrm{j}} \operatorname{Top}^{0}\left[\mathrm{FP} \text { quién } \mathrm{i}_{\mathrm{i}} \mathrm{F}_{\mathrm{j}} \mathrm{t}_{\mathrm{j}}\right]\right]\right.\right.
$$

Interactions between in-situ wh-phrases and adverbial quantifiers never give rise to distributive interpretations :
a. ¿Qué compráis cada día? what you-buy each day
b. Cada día comprais ¿qué? each day you-buy what

Whereas (63a) can be interpreted in a distributive fashion, as asking for each different day the things which are bought in that day, (63b) can only mean « what is the thing $x$ such that you buy x every day ». In our analysis, this must mean that they cannot reach the position of clitic left dislocated constituents. In fact, adverbial quantifiers sound very odd when they precede overtly moved $w h$-phrases $(64 \mathrm{a}, \mathrm{b}){ }^{10}$. Their natural position is after the $w h$-word $(65 \mathrm{a}$, b) : 
(64) a. ??Cada día, ¿qué compráis?

Each day, what you-buy

b. ??Cada día, ¿quién viene?

each day, who comes

(65) a. ¿Qué compráis cada día?

b. ¿Quién viene cada día?

\section{Inversion}

An expected phenomenon in approaching apparent in-situ configurations in terms of a movement analysis is the presence of inversion, a typical side effect of A'-movement (see Torrego, 1984, for Spanish; Pesetsky and Torrego (2001) for a recent comparative approach to movement related inversion). The presence of inversion in the in-situ strategies of other romance varieties, such as Bellunese, as studied by Munaro (1999) and Munaro, Pollock and Poletto (2001) serves as strong empirical evidence for the movement hypothesis. In Spanish, the overt movement of some operators such as $w h$-phrases and foci obligatorily induces inversion:

$$
\begin{aligned}
& \text { a. ¿Qué ha comprado Juan? } \\
& \text { what has bought Juan } \\
& \text { b. ¿QQué Juan ha comprado? }
\end{aligned}
$$

If in-situ wh-phrases in Spanish are the result of overt focus movement plus remnant topicalization, we would expect to find "derivational traces" of the overt focus movement operation in the remnant, perhaps as a postverbal position for the subject. This expectation is, apparently, not met:

$$
\begin{array}{llll}
\text { a. Tu padre ha comprado } & \text { ¿qué? } \\
\text { your father has bought } & \text { what } \\
\text { b. *Ha comprado tu padre } & \text { ¿qué? } \\
\text { has bought your father } & \text { what }
\end{array}
$$

That is, the derivation that we postulate for the in-situ cases consists of the following steps :

\footnotetext{
a. Focus movement + «inversion »:

[FP qué $\mathrm{F}_{\mathrm{i}}^{0}\left[\right.$ T⿱ ha comprado tu padre $\left.\mathrm{t}_{\mathrm{i}}\right]$ ]

b. Remnant topicalization:

[TopP $\left[\text { TP ha comprado tu padre } \mathrm{t}_{\mathrm{i}}\right]_{\mathrm{j}} \operatorname{Top}^{0}\left[{ }_{\mathrm{FP}}\right.$ qué $\left.\left.\mathrm{F}_{\mathrm{i}} \mathrm{F}_{\mathrm{j}} \mathrm{j}\right]\right]$
}

In our terms, «inversion» must be understood as in Alexiadou and Anagnastopoulou (1998): Spanish checks the EPP feature of T via verb movement (see also Suñer, 1994), and not through DP movement. Spanish preverbal subjects are thus not in Spec of TP (as in, say, English) but in a 
"dislocated" position (see Barbosa, 1995; Ordoñez and Trevino, 1999; Ordoñez, 1997 ; Zagona, 2001, among others). Postverbal subjects are thus insitu, and Case and agreement features of the postverbal subject are checked through Agree (Chomsky, 2000; 2001). So called "obligatory inversion" in the context of overt operator movement may be understood as simply the fact that there is no dislocation site below the focus phrase in Spanish. In this regard, Spanish is unlike Italian (Rizzi, 1997 : 296), as shown by the following contrast:

a. Credo che QUESTO a Gianni, domani, gli dovremmo dire I-think that this, to Gianni, tomorrow to-him we-will-have-to tell

b. *Creo que ESTO a Juan, mañana, habrá que decirle

Nothing can intervene between the focus and the finite verb/auxiliary in Spanish $^{11}$.

The issue then is why inverted subjects seem to be impossible in the context of in-situ questions, which, in our hypothesis, undergo focus movement. We will show that the restriction against postverbal subjects in the remnant is only apparent. Postverbal subjects in the remnant become possible if the preverbal domain contains a topic. Consider the following piece of dialogue:

(70) Speaker 1 :

Juan compró un libro, un reloj y una guitarra para regalárselas a

'Juan bought a book a clock and a guitar to offer them to

Jokin, a Maite y a Oihana.

Jokin to Maite and to Oihana;'

Speaker 2:

Y la guitarra, se la regaló Juan a quién? and the guitar, CL CL offer Juan to whom

'And the guitar, Juan offered it to whom?'

As we can see in the in-situ question of Speaker 2, a postverbal subject is perfectly possible in an in-situ question. The only difference between the impossible inverted structure in (67b) and the possible one in (70) is that in the latter a clitic left dislocated topic precedes the sentence. The preverbal position of the subject is thus part of a broader generalization, already discussed in Uribe-Etxebarria (2002): the highly restricted contexts allowing in-situ wh-phrases in Spanish also require contrastive topics. A further manifestation of that generalization is the ban against null subjects in contexts such as (71) (Uribe-Etxebarria, 2002:221):

(71) Speaker 1:

Fuimos a la tienda a comprar huevos, leche y café. we-went to the store to buy eggs, milk and coffee 
Mi madre compró los huevos

my mother bought the eggs

a. Speaker 2:

*Y compraste ¿qué?

and bought-2sing what

b. Y tú compraste ¿qué?

and you bought what

The ungrammaticality of (71b) can be straightforwardly accounted for under the assumption that contrastive topics must be overt.

Given the generalization that in-situ questions require a contrastive topic, and that this topic position may be occupied by the subject (in fact, must, if there is no other topic available) the absence of inversion in the insitu cases such as (67b) is just a consequence of (subject) topicalization. In (67a) therefore, the subject must be in a position external to the remnant moved TP:

$$
\left[{ }_{\text {TopP }} \text { tu padre Top }{ }^{0}\left[{ }_{\text {TopP }}\left[{ }_{T P} \text { ha comprado } t_{i}\right]_{j} \text { Top }^{0}\left[{ }_{F P} \text { qué }_{i} F^{0} t_{j}\right]\right]\right]
$$

\section{NOTES}

1. This is part of an ongoing research which began almost three years ago. Parts of this work have been presented at the International Workshop on Wh-Movement (Leiden/Utrecht, OTS) in 2001, and at the Workshop on the CP-Domain organized in the context of the Fédération Typologie et Universaux of CNRS (Paris, 2002). We thank the audiences there for helpful comments and discussion. Earlier presentations and contributions are acknowleged in Uribe-Etxebarria (2002). Myriam UribeEtxebarria and Ricardo Etxepare gratefully acknowledge financial support from grants 9/UPV 00033.130-13888/2001 and 9/UPV 00114.130-16009/2004 by the University of the Basque Country and BFF2002-04238-C02-01 from the MCYT (Ministerio de Ciencia y Tecnología, Spain). Ricardo Etxepare acknowledges support from the Fédération "Typologie et universaux linguistiques" (CNRS), through the project "L'architecture de la phrase" directed by Hans Obenauer and Alain Kihm.

2. Many speakers do not agree with Bošković's (1998), Chang's (1997) and Rooryck \& Cheng's (2000) claim that embedded in-situ wh-phrases are impossible in French. Obenauer (1994) discusses a number of well-formed examples with embedded wh-in-situ ( $c f$. (i)), including wh-in-situ questions in islands ( $c f$. (ii)), arguing in favor of LF-movement (and pied-piping of certain islands, like the adverbial one in (ii)):

(i) Tu penses [qu'il serait plus prudent [de passer par où] ?

You think that it would be more cautious to go through where [=which way]]

Il s'est défendu [en accusant qui]] ?

He defended himself by accusing who

As far as we know, there is no systematic description or analysis of the whole range of facts related to in-situ wh-phrases in French and the possible subsystems they may give rise to. For the purpose of this paper, we have concentrated on the dialect/idiolect identified and described in Chang (1997), Bošković (1998), Cheng and Rooryck (2000) and Mathieu (2002). 
3. Honcoop's analysis is semantically based, and cast in the framework of Dynamic Semantics (Chierchia, 1995; Dekker, 1998, among others). Honcoop capitalizes on the fact that the operators which block the linking of the indefinite restriction and the wh-operator are the same which block cross sentential anaphora, and provides a unified analysis.

4. Zubizarreta (1994:44) attributes the ungrammaticality of (17b) and (18b) to the fact that negative polarity items such as nada "anything" cannot be destressed. Cardinaletti (2001) speculates that nada, and its Italian equivalent niente are weak elements, in the sense of Cardinaletti and Starke's typology (1999). Being weak elements, nada and niente are forced to move from their base position. Cardinaletti observes that examples analogous to Spanish (17b) and (18b) improve in Italian with heavier n-words. Those heavier elements include [+human] n-word nessuno "anyone/nobody" and complex n-words such as nessuna cosa "any thing/no thing":

(i) a. *Non ha fatto nessuno niente

b. Non ha fatto niente nessuno

(ii) a. Non ha fatto nessuno nessuna cosa

b. Non ha fatto nessuna cosa nessuno

Observe that the Spanish cases do not improve with heavier elements:

(iii)a. *No ha hecho JUAN, ninguna cosa

neg has done Juan any thing

b. *No ha hecho ESE TRABAJO, nadie

neg has done that work, nobody

Nadie and ninguna cosa, on the other hand, can be marginally left dislocated, in which case they must be destressed:

(iv) a. Nadie, no ha venido nobody, neg has come

"It is not the case that nobody came"

b. Ninguna cosa, es raro que hayan comprado any thing is strange that have-subj bought

"Nothing, it is strange that they should have bought"

So the reason for the ungrammaticality of (17b) and (18b) cannot be the destressing operation per se. We note that both nadie and ninguna cosa in (iv) have a universal, quantificational reading, and not an existential one, as shown in the translations. Such a reading is to be expected in cases where the $n$-word takes scope over negation, as is the case in (iv). We could then wonder why the right dislocated cases do not allow for such a reading. In our analysis, the reason is clear: the sentence final, right dislocated $n$-word does not take scope over negation, which is inside the remnant moved constituent. It is not c-commanded by negation either, for the same reason. No reading (universal or existential) is thus licensed in the sentence final position of in-situ constructions.

5. Some of them are not directly testable in Spanish, such as ne-cliticization (i), or presence of Case features in certain colloquial varieties (ii):

(i) a. L'abbiamo invitato noi, a Gianni

CL have invited we, to Gianni

b. Abbiamo invitato noi, (*a) Gianni 
(ii) a. *Ne lo/ lo ne ha comprato Gianni, uno CL CL CL CL has bought Gianni, one

b. Ne ha comprato Gianni, uno

CL has bought Gianni, one

In (ia), a Right Dislocation, the Case marker in the right dislocated constituent is obligatory. In (ib), a case of Marginalization, it is excluded. In (ii), ne-cliticization is possible out of a Marginalized constituent (showing the object is truly in-situ), but not out of a Right Dislocated one.

6. Contrastively focused adjuncts of the relevant sort are perfectly possible, as shown in (i):

(i) a. POR ESO emigró mi tío y no por lo que tú mencionas because that emigrated my uncle, and not because what you are saying

b. ASÍ llego mi tío, y no como tú dices

thus arrived my uncle, and not as you say

7. Cheng and Rooryck (2003 : 5) observe that in Portuguese, the same configurations only show embedded scope for the in-situ wh-phrase:

(i) O Joao quer saber se tu compraste o que

the Joaowants to know if you bought what

'Joao wants to know what you bought'

Cheng and Rooryck propose an analysis of Portuguese in-situ questions inside whdependents which is identical to their analysis of in-situ wh-phrases in French. The reason why in-situ wh-phrases in French and in-situ wh-phrases in wh-dependents in Portuguese should behave in the same way is related to the status of the Portuguese complementizer se, which as the French intonational morpheme of root questions is ambiguous between a yes/no question marker and a partial question marker. The indeterminate status of se in Portuguese forces the attraction of $w h$-features from the in-situ wh-phrases. Cheng and Rooryck (2003: 8) observe that inside wh-dependents, in-situ wh-phrases undergo intervention effects, exactly as in French. We present two examples :

(ii) a. *O Joao quer saber se a Maria nao viu quem Joao wants to know if Maria neg saw whom 'Joao wants to know who Maria did not see'

b. *O Joao quer saber se todo o estudante viu quem Joao wants to know if every the student saw whom 'Joao wants to know who every student saw'

Also as in French, se cannot be related to an embedded wh-phrase in-situ:

(iii) *O Joao quer saber se a Maria pensa [que o Pedro viu quem] Joao wants to know if Maria thinks [that Pedro saw whom] In the absence of the indeterminate complementizer se, wh-phrases in-situ in Portuguese can be embedded (Cheng and Rooryck 2003 : 6):
O Joao
pensa que
Maria viu
quem?
Joao thinks that Maria saw whom
'Who does Joao think that Maria saw?'

The Spanish facts seem to support Cheng and Rooryck's analysis: Spanish si, unlike Portuguese $s e$, is unambiguous as a question marker: it only marks yes/no questions. Accordingly, wh-phrases in $w h$-dependents behave as in main clauses, showing no intervention effects and no locality effects of the French type. 
8. Wh-phrases in-situ, in Spanish (also in Portuguese, Cheng and Rooryck, 2003), can occur inside strong islands :

(i) a. Tú has visto [al juez que detuvo ¿a quién]?

you have seen the judge who jailed whom

"Who is the $\mathrm{x}$ such that you have seen the judge who jailed $\mathrm{x}$ ?"

b. Tú te enfadaste [porque vino quién]?

you got angry because came who

"Who is the x such that you got angry because x came?"

This possibility extends to relative clauses and adjuncts:

(ii) a. Tú viste [a un juez que se suicidó ¿por qué]?

You saw a judge who CL suicide why

'What is the reason such that you saw a judge who commited suicide because of that reason?'

b. Se abre una investigacion [cuando alguien muere de qué]?

CL opens an inquiry when someone dies of what

'What is such that an inquiry is opened when someone dies of it?'

Given the fact that in-situ adjuncts are otherwise sensitive to islands, we have to reject the idea that somehow, the relevant configurations are immune to the usual constraints on extraction. Etxepare and Uribe-Etxebarria (in preparation) argue that they reflect cases of massive pied piping, of the sort one can see in examples such as (iii):

(iii) [Cuando alguien muere de qué $]_{i}$, dices que se abre una investigacion $t_{i}$ ? when someone dies of what, you-say that CL opens an inquiry

'What is such that when someone dies of it, you say that an inquiry is opened?'

In (iii), the whole adjunct clause is moved from an embedded sentence to the left periphery, as if it were a $w h$-phrase. Several conditions holding of (iii) are shown to hold also of (i) and (ii).

9. This is unlike English (as described by Nissenbaum, 2000) or Portuguese, as presented by Cheng and Rooryck (2003 : 15). In both English and Portuguese, anaphors in in-situ positions can be bound "long distance":

(i) a. $\mathrm{Who}_{\mathrm{i}}$ thinks Mary was looking at which picture of himself $\mathrm{f}_{\mathrm{i}}$ ?

b. Quem ${ }_{i}$ pensa que a Maria viu que fotografia de $\mathrm{si}_{\mathrm{i}}$ ?

This fact is crucial for the "covert movement" analysis of both Nissenbaum and Cheng and Rooryck. But the analysis cannot be applied to Spanish. Obviously, this raises the question of what exactly distinguishes English and Portuguese from Spanish. It seems unlikely that it has anything to do with the availability of covert movement, if such option exists. A different possibility is that it is related to the feature composition of the relevant anaphors, and the nature of long distance licensing. If this is the case, the basis for a covert movement analysis of (ia, b) is weakened.

10. Some speakers accept $(61 \mathrm{a}, \mathrm{b})$, but in that case, they do not get a distributive reading. The sentences are interpreted as 'What is the thing $\mathrm{x}$ such that you buy $\mathrm{x}$ each and every day?'. The sentences in $(62 \mathrm{a}, \mathrm{b})$ allow a distributive reading.

11. In this, focus operators behave differently from preverbal [+human] and specific wh-phrases, which do marginally admit intervening adverbs, scene setting topics and conditionals (Olarrea, 1996, among others):

(i) a. ¿Quién, finalmente, va a hacer de intérprete?

who finally will do the translator 
b. ¿Quién de vosotros, si la noticia se confirma, irá a contársela al jefe? who among you if the news gets confirmed, will-go tell the boss

c. ¿En qué lugar, mañana, se va a celebrar el juicio? in what place tomorrow will be the trial

\section{REFERENCES}

Alexiadou, Artemis; Anagnastopoulou, Elena (1998). Parametrizing AGR: Word Order, V-Movement and EPP-Checking, Natural Language and Linguistic Theory 16, 3: 491-539.

BECK, Sigrid (1996). Wh-Constructions and Transparent Logical Form. Ph.D. Dissertation, University of Tubingen.

BošKović, Zeljko (2000). Sometimes in Spec CP, sometimes in-situ. In Roger Martin et al. (eds.), Step by Step: 53-88. Cambridge MA: MIT Press.

CAMPos, Hector; ZAMPINI Maria (1990). Focalization strategies in Spanish, Probus 2: 47-64.

Cardinaletti, Anna (2001). A second thought on emarginazione: Destressing vs 'Right Dislocation'. In Guglielmo Cinque and Giampaolo Salvi (eds.), Current Studies in Italian Syntax. Essays offered to Lorenzo Renzi: 117-136. North Holland Linguistic Series 59. Amsterdam: Elsevier.

CARdinaletti , Anna (2002). Against optional and null clitics. Right Dislocation vs. Marginalization. Studia Linguistica 56-1 : 29-57.

Ceccehetto, Carlo (1999). A Comparative Analysis of Left and Right Dislocation in Romance. Studia Linguistica 53-1: 40-67.

Chang, Lisa (1997). Wh-in-situ phenomena in French. M.A. Dissertation, University of British Columbia.

Cheng , Lisa L.; Rooryck, Johan (2000). Licensing wh-in-situ. Syntax 3.1 : 1-20.

Cheng, Lisa L.; Rooryck, Johan (2003). Types of wh-in-situ. Ms. Leiden University.

Cinque, Guglielmo (1993). A null theory of phrase and compound stress. Linguistic Inquiry 24: 239-298.

EtXepare, Ricardo; Myriam URIBe-EtXEBARria (2003). In-situ wh-phrases in Spanish: Scope and Locality at the Right Edge. In preparation. Ms. CNRS \& UPV-EHU.

Kayne, Richard (1998). Overt versus Covert Movement. Syntax 1: 128-191.

KAYNE, Richard (2000). Parameters and Universals, Oxford Studies in Comparative Syntax. Oxford: Oxford University Press.

Koster, Jan; Eric Reuland (eds.) (1991). Long Distance Anaphora. Cambridge: Cambridge University Press.

Honcoop, Martin (1997). Dynamic Excursions on Weak Islands. The Hague: Holland Academic Graphics.

JiméneZ, Maria Luisa (1997). Semantic and Pragmatic Conditions on Word Order in Spanish. Ph.D. Dissertation. Georgetown University, Washington D.C.

MathiEu, Eric (2002). The Syntax of Non-Canonical Quantification: A Comparative Study, Ph.D. Dissertation, University College London, London. 
Munaro, Nicola; Poletto, Cecilia; Pollock, Jean-Yves (2001). Eppur si muove! On Comparing French and Bellunese Wh-Movement. In press. Linguistic Variation Volume 58, Amsterdam, New York, Tokyo.

Nissenbaum, Jonathan W. (2000). Investigations of Covert Phrase Movement. Ph.D. Dissertation, MIT.

OBenauer, Hans-Georg (1994). Aspects de la syntaxe A-barre. Effets d'intervention et mouvements des quantifieurs. Thèse d'État, Université Paris 8.

Olarrea, Antxon (1996). Pre- and Postverbal Subject Positions in Spanish: A Minimalist Account, Ph.D. Dissertation, University of Washington, Seattle.

ORdoñEz, Francisco (1997). Word Order and Clause Structure in Spanish and Other Romance Languages. Ph.D. Dissertation, City University of New York, New York.

Pesetsky, David (1987). Wh-in-situ: Movement and Unselective Binding. In Eric J. Reuland and Alice G.B. ter Meulen (eds.), The Representation of (In) definiteness: 98-129. Current Studies in Linguistics. Cambridge, MA: MIT Press.

Pesetsky , David (2000). Phrasal Movement and Its Kin. Cambridge MA: MIT Press. Poletto, Cecilia; Pollock, Jean-Yves (2003). On Wh-clitics, Wh-doubling and Apparent Wh-in-situ in French and some North Eastern Italian Dialects. This volume.

Pollock, Jean-Yves (2001). Three arguments for Remnant IP Movement in Romance. In press. Asymmetry in Grammar, volume 1: Syntax and Semantics. Amsterdam/Philadelphia: John Benjamins.

ReInhart, Tanya; Reuland, Eric (1991). Anaphors and logophors: an argument structure perspective. In Koster and Reuland (eds.) : 283-321.

RIzZI, Luigi (1990). Relativized Minimality, Linguistic Inquiry Monograph 16. Cambridge: MIT Press.

RIzzI, Luigi (1997). The fine structure of the left periphery. In Liliane Haegeman (ed.), Elements of Grammar : Handbook of Generative Syntax: 281-337. Dordrecht: Kluwer Academic Publishers.

SUÑER, Margarita (1994). V-movement and the Licensing of Argumental Wh-Phrases in Spanish. Natural Language and Linguistic Theory 12: 335-372.

TORREGO, Esther (1984). On Inversion in Spanish and Some of its Effects. Linguistic Inquiry 15: 103-129.

Torrego, Esther; Pesetsky, David (2000). T-to-C Movement: Causes and Consequences. In Michael Kenstowicz (ed.), Ken Hale : a Life in Language. Cambridge MA: MIT Press.

UriagereKa, Juan (1995). A Focus Position in Western Romance. In Katalin Kiss (ed.), Discourse Configurational Languages: 153-175. Oxford: Oxford University Press.

Uribe-EtXebarria, Myriam (2002). In-situ questions and masked movement. Linguistic Variation Yearbook 2: 215-255.

ZaGona, Karen (2001). The Syntax of Spanish, Cambridge Syntax Guides, Cambridge University Press.

Zubizarreta, Maria Luisa (1998). Prosody, Focus and Word Order. Cambridge, MA : MIT Press. 


\section{RÉSUMÉ}

Cet article analyse les questions à syntagme-wh (qu-) in-situ en espagnol. Il montre que la position de surface de ces syntagmes est le résultat d'un mouvement visible vers une position focale dans la péripherie gauche. La position post-verbale dans laquelle les syntagmes-wh apparaissent résulte d'un mouvement postérieur par-dessus la position focale, dans l'esprit des propositions récentes de Kayne (1998, 2000). L'analyse défendue ici conduit à distinguer le phénomène in-situ en espagnol des phénomènes correspondants rencontrés dans les autres langues romanes, dont le français (Chang, 1997; Cheng et Rooryck, 2000; Bošković, 2000). Il est ainsi démontré que les mécanismes syntaxiques supposés déterminer la distribution des syntagmeswh-in-situ dans ces langues doivent être modifiés dans le cas de l'espagnol. Dans une perspective comparative, les données de l'espagnol étayent une approche 'pluraliste' des stratégies in-situ (Cheng et Rooryck, 2003), selon laquelle la notion descriptive de syntagme in-situ recouvre un domaine grammatical non homogène. D'un point de vue théorique, notre analyse appuie l'idée que beaucoup de phénomènes analysés comme mouvement abstrait (en Forme Logique) dans la tradition du Gouvernement-Liage doivent être réanalysés comme cas de mouvement visible (masqué).

\section{MoTS-CLÉS}

Focus contrastif, mouvement abstrait, mouvement résiduel, dislocation à droite, espagnol, wh-in-situ. 